\title{
صلة الفلسفة بالنهو عند ابن رشد
}

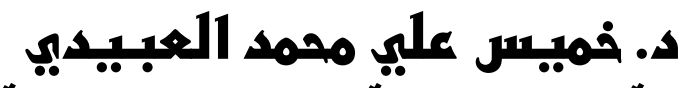

عضو هيئة تدريس جاميسة بنغازي- الجماهيرية الليبية كلية الآداب، قسم ألفّلسفة 


$$
\text { }
$$




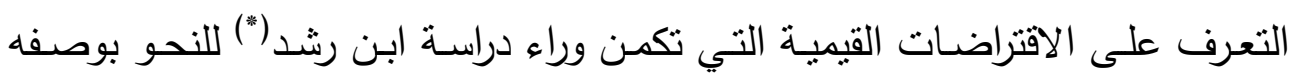

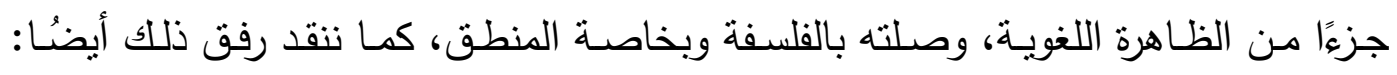

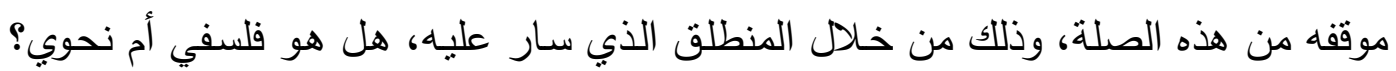
أم أن الطابع الجدلي هو ما يعكس موقفه من أي الصلة.

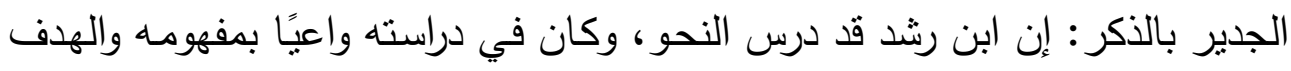

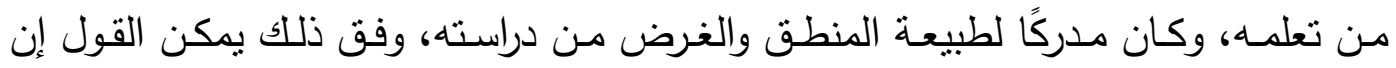

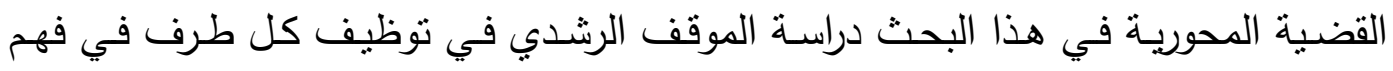

كما يحتوي البحث على النقطتين الآتيتين:

1- التحليل المنطقي للغة.

r- الخاصية الدنطقية للغة.

بعقب ذللك أهم النتائج الني يمكن التوصل إليها في هذا البحث.

أولاً: التحليل المنطقي للغة:

بادئ ذي بدأ ينقسم الكلام وفق ابن رشد إلى ثلاثة أقسام: اسم، وكلمة (فعل)، وأداة

\section{تعريف الاسم:}

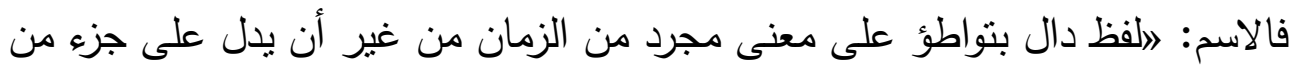

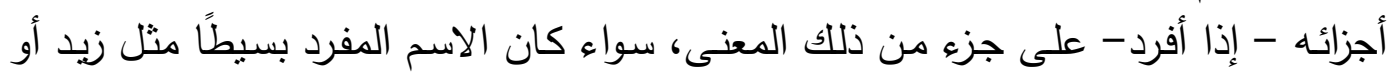

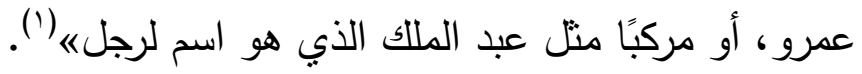

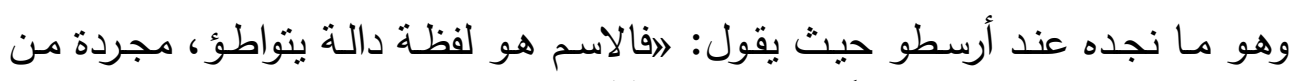

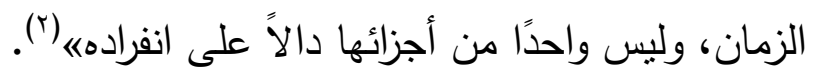

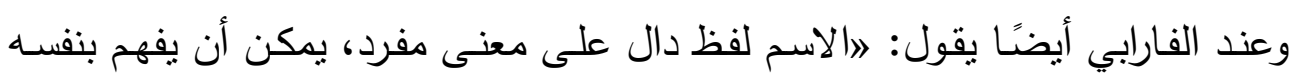

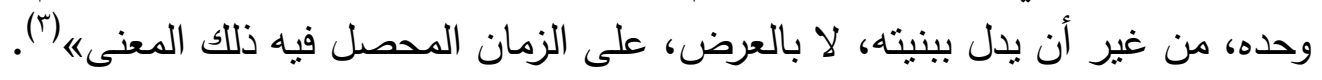

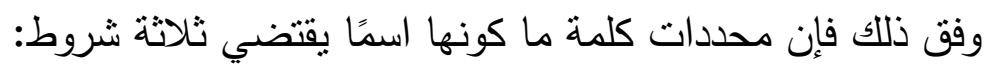




$$
\begin{aligned}
& \text { أولها: لابد أن يتم التواطؤ عليها. } \\
& \text { ثانيها: لابد أن تكون مجردة من الزمان. } \\
& \text { ثُالثها: عدم دلالة جزء من أجزائها على معنى بذاته. لتحن. }
\end{aligned}
$$

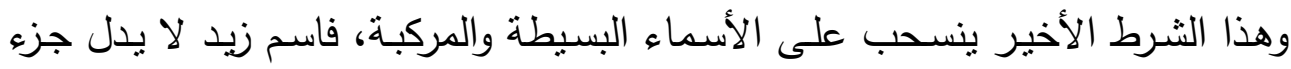

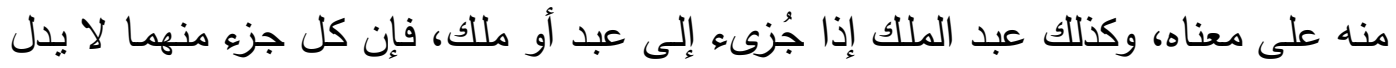
بذاته على المقصود من الاسم المركب، أي عبد الملك.

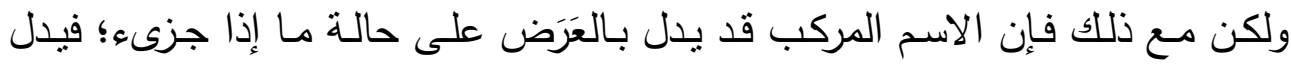

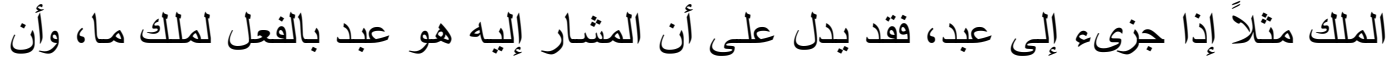
الملاك قد يدل على مالك لذلك العبد.

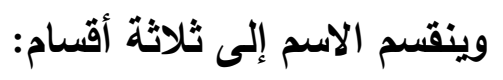

أولها: إلى بسيط ومركب، وقد سبق نوضيحهما. وثثانيها: إلى محصل وغير محصل.

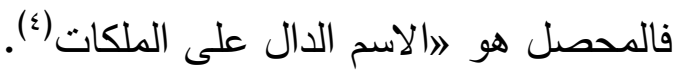
منل قولنا: إنسان وفرس.

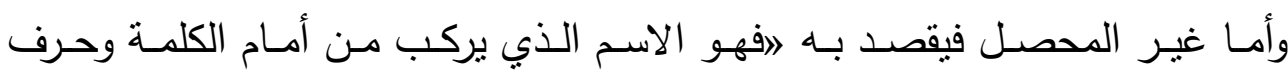
مثل قولنا: لا إنسان، ولا حيوان.

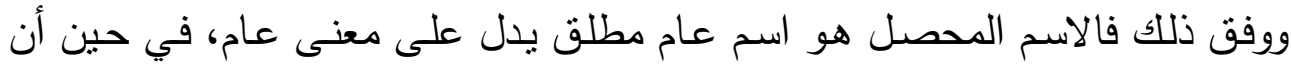
الاسم غير المحصل هو اسم ما لا يدل على معنى مطلق كونه مقرونًا بحرف السلب.

$$
\text { وثالثها: الاسم المصرف وغير المصرف. }
$$

فالاسم الهصرف هو ما يقبل حركات الإعراب "رفعًا ونصبًا وجرًا"، ويطلق عليه ابن

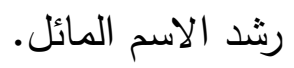

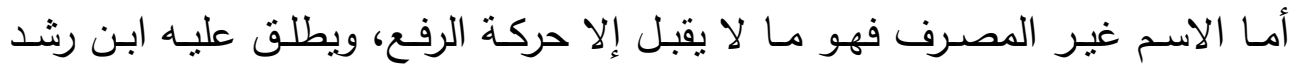

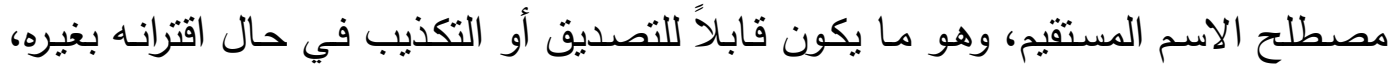
ومثال ذللك: (زيد كان أو زيد وجد) (َ). 


\section{تعريف الكلمة (الفعل):}

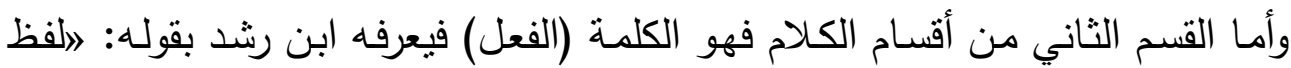

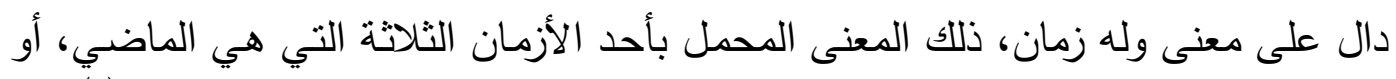

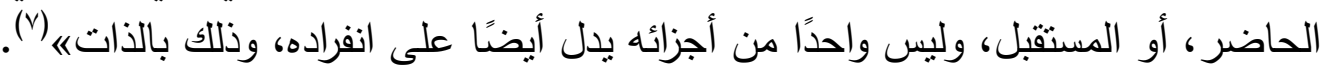

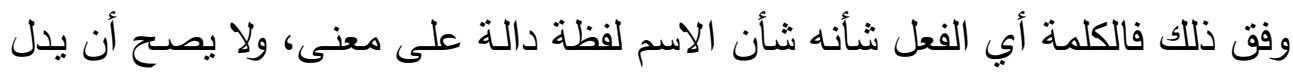

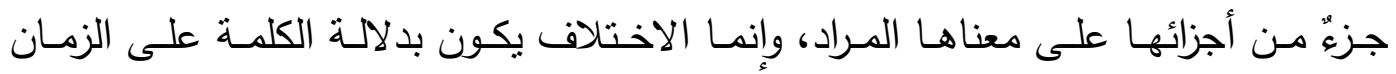
الدحصل: ماض، وحاضر ، ومستقبل.

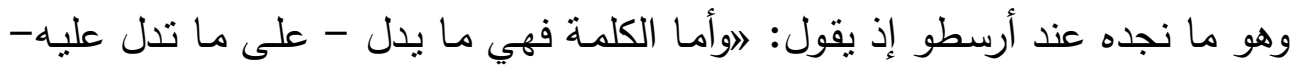

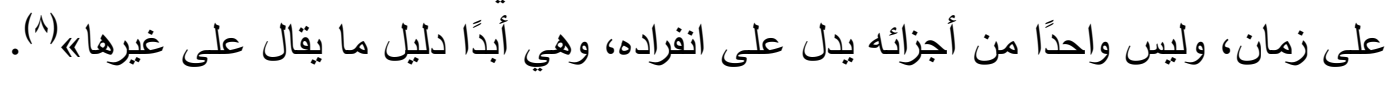

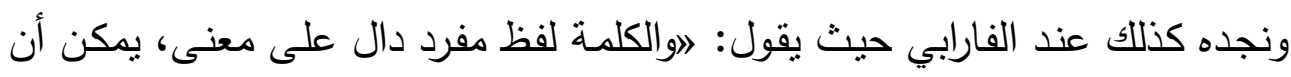

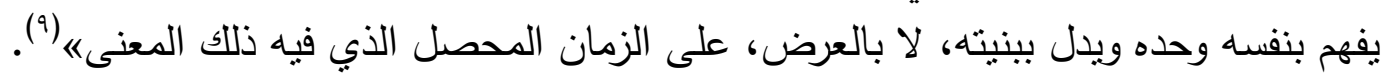

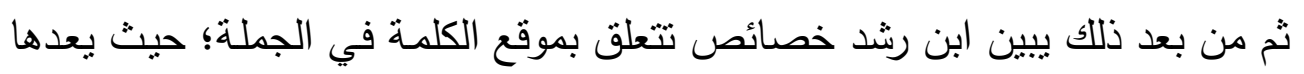

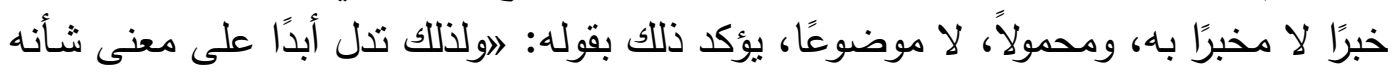

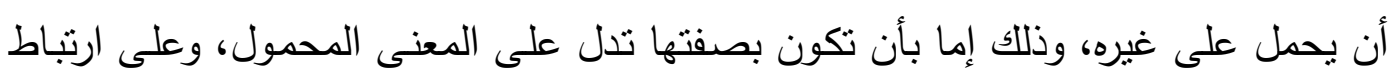

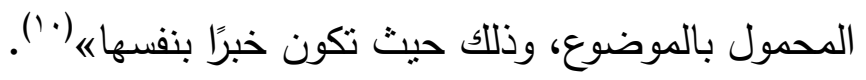

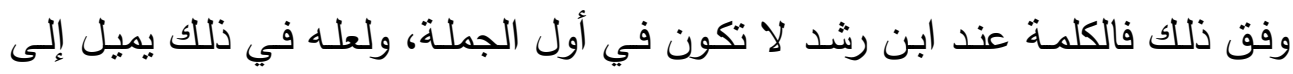

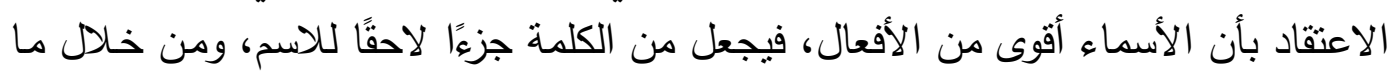

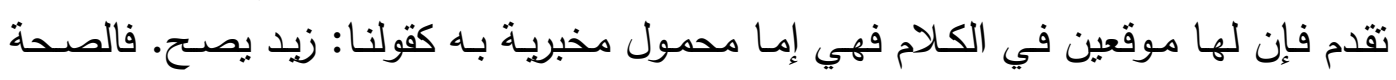

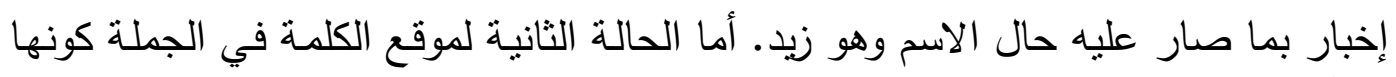

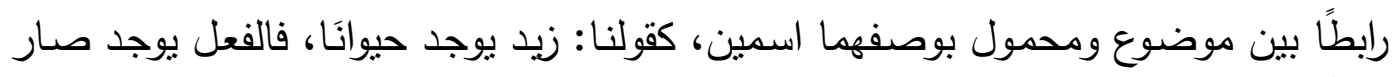

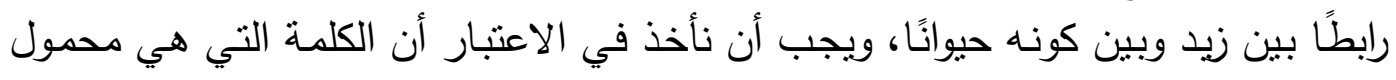

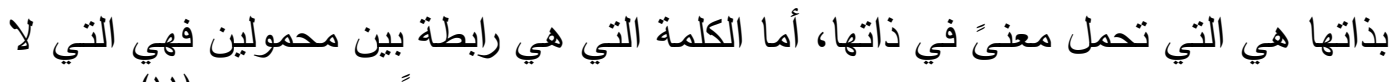

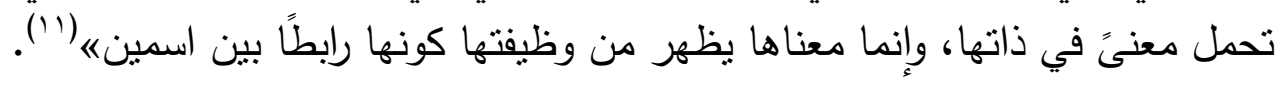

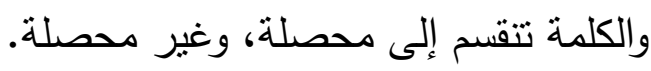

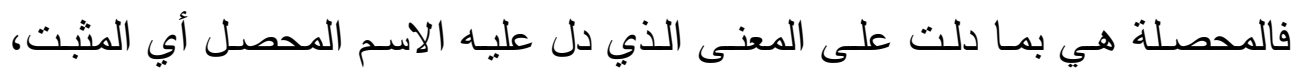
وعلى زمان المعنى كقولنا: زيد يصح. 
وأما الكلمة غير المحصلة في التي تدل على الاسم غير الدحصل وعلى زمان المعنى

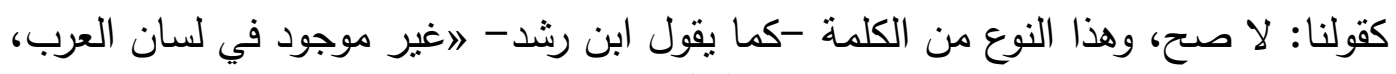
كما كان الاسم غير المحصل غير موجودها (ז').

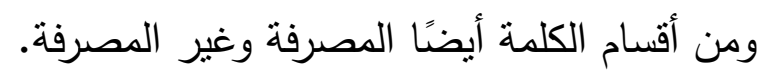

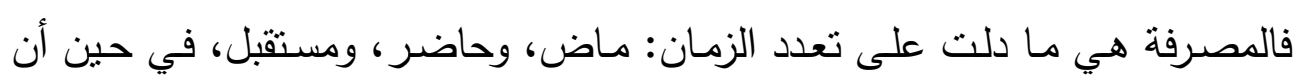

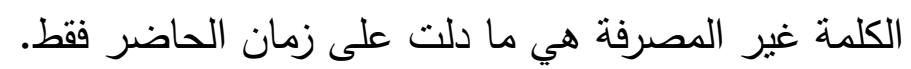

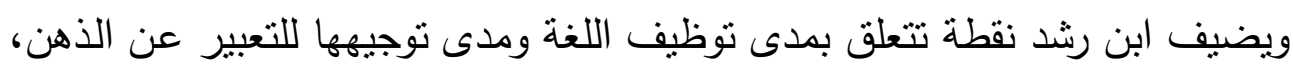

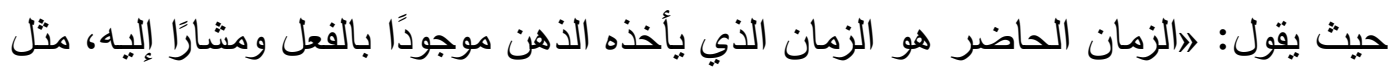

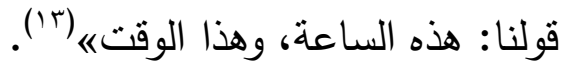

\section{تعريف الأداة (الحرف):}

القسم الثالث من أقسام الكلام هو الأداة، حيث نجد ابن رشد يعرفها بقوله: الفظ يدل

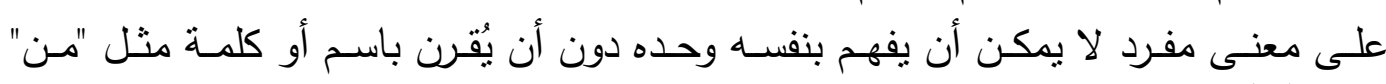
وعلى" (i) (1) (2)

وفي موضع آخر يعرف الأداة مستخدمًا مصطلح حرف عوضًا عنها: الفظ يدل على الألى

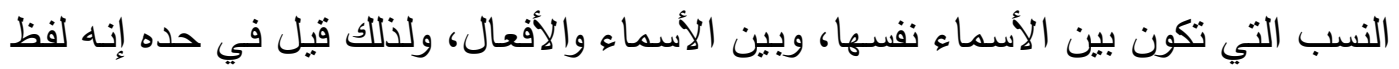
يدل على معنى في غيره(1).

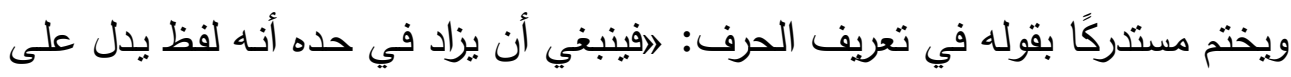

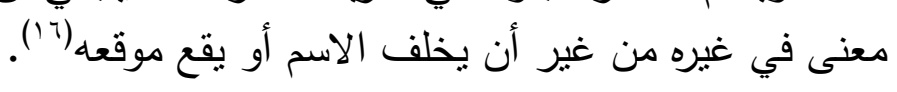

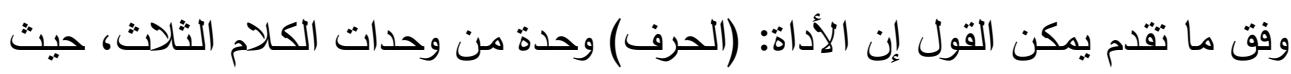

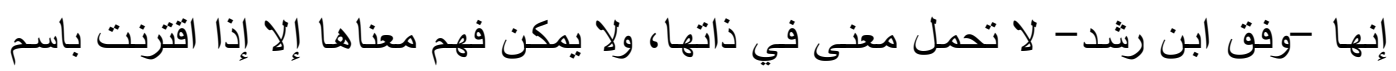

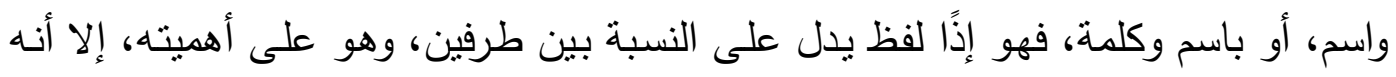
أضعف من الاسم، إذ لا يمكن أن يحل محله في الكلام.

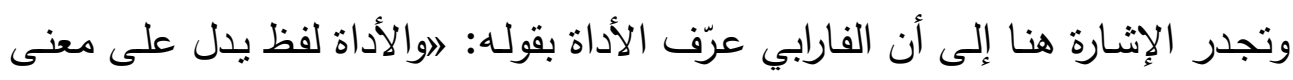

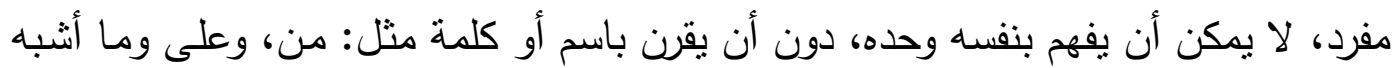

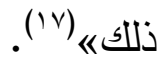
وختامًا لهذا المبحث نعرض لما قدمه ابن رشد من تفرقة بين الكلام والقول. 


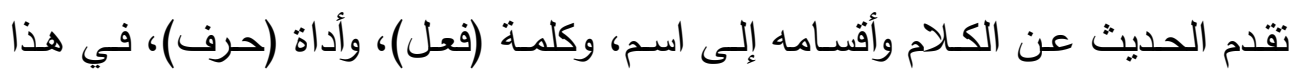

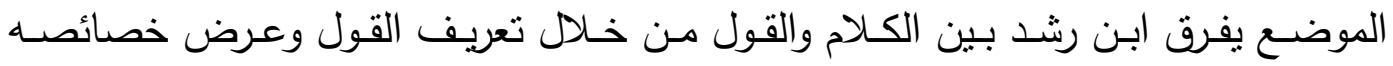

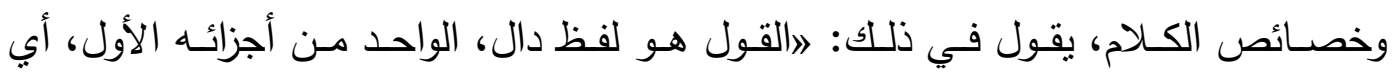

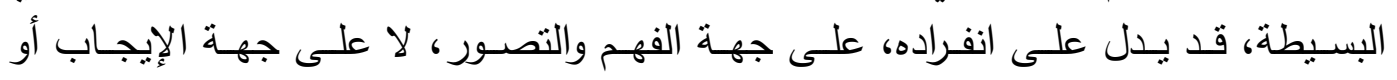

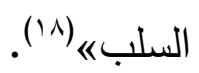

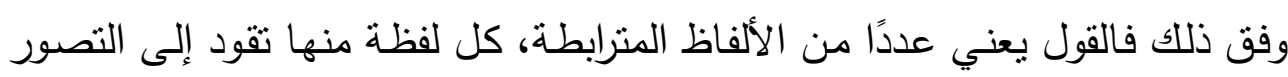

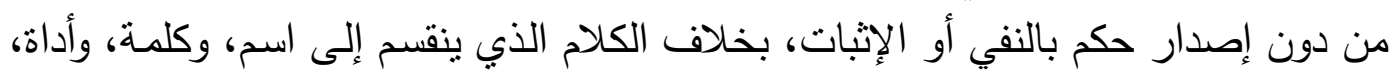

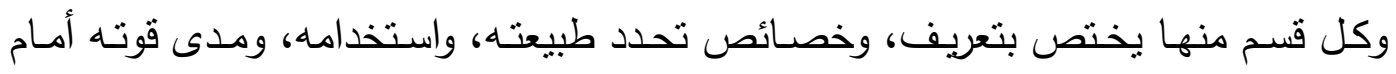

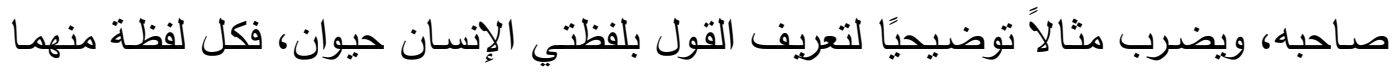

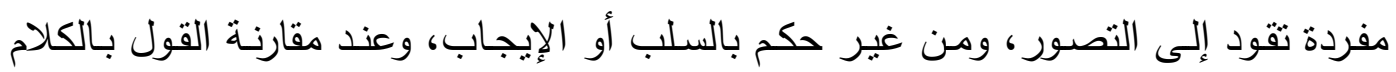

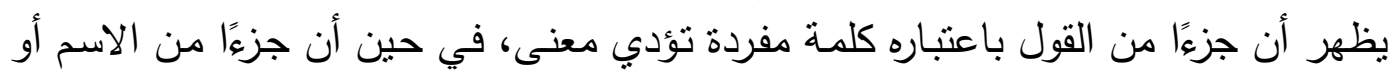

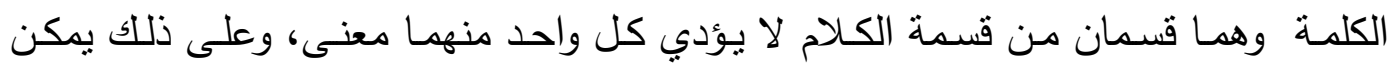

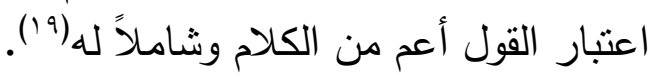

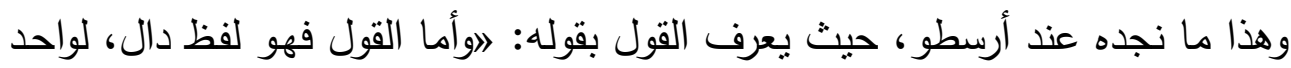

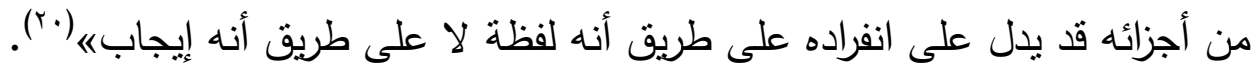

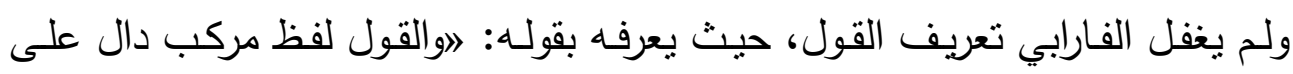

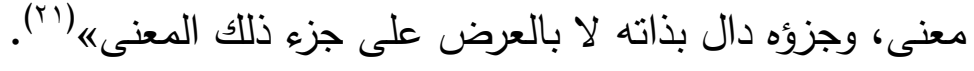

\section{ثانيا: الخاصية المنطقية للغة : مجنة}

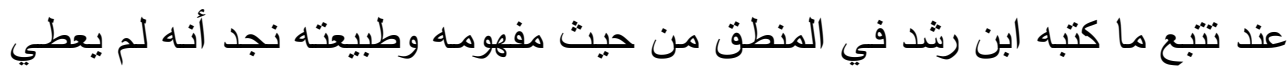

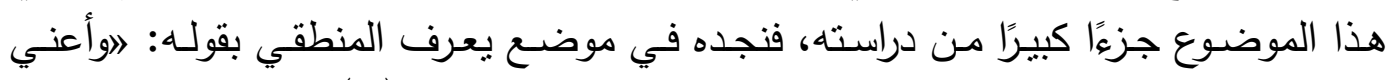

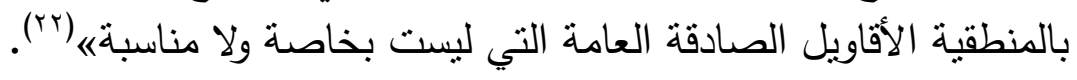

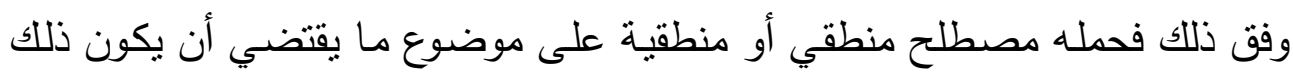

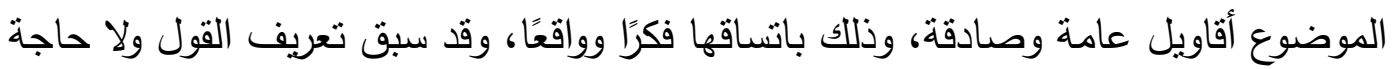
إلى إعادته هنا.

وفي موضع آخر يعرف المنطقي بوصفه الثخص المشتغل بعلم المنطق حيث يقول:

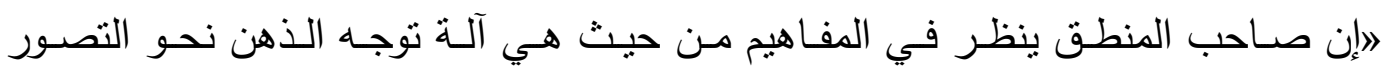


لماهيـات الأثـياء، وينظـر فيهـا صـاحب هـذا العلـم مـن حيـث هـي تـدل على طبائع الأنشياء《r)

بناءً على ذلك فإن صاحب المنطق أو المشتغل به يجب أن يأخذ في حسبانه مهنتين

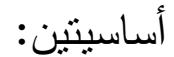

1- يجب أن يهنتم بدراسـة الحدود أي التعريفات التـي توضـح مفـاهيم الموضـوعات المـراد تعريفها حين يكون في الإمكان الوصول إلى تصورات مقبولة لها، وذلك من خلاد تحديد التهريد ماهينها.

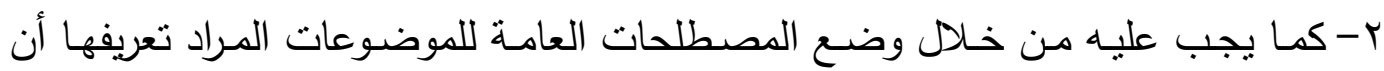

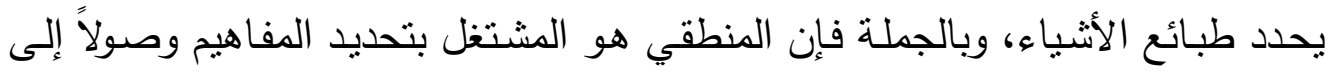
الماهية والطبيعة المكونة للموضوع المعرف.

\section{أقسام المنطق: - 20 - 20}

يعرض ابن رشد أقسام المنطق كما عرضها أرسطو من قبل على النحو التالي:

$$
\begin{aligned}
& \text { 1- الألفاظ من حيث كليتها وجزئيتها. الجدل. }
\end{aligned}
$$

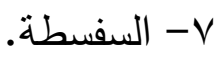

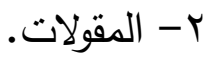

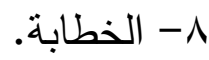

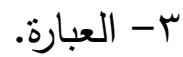

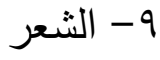

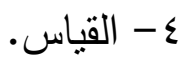

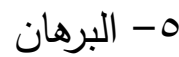

نقطة أخرى يطرحها ابن رشد في صلة اللغة بالمنطق، وذللك من خلال دراسة التساوق

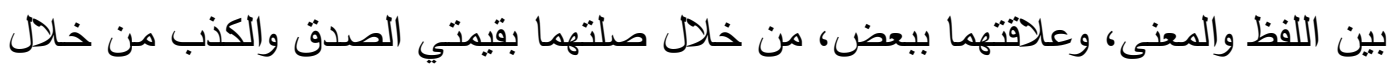

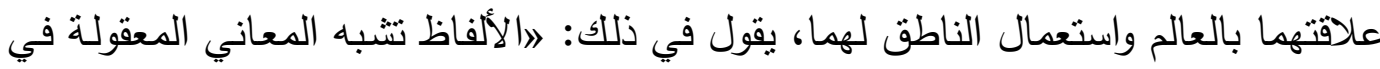

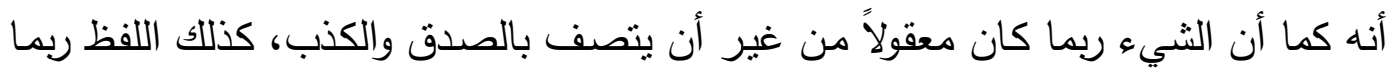

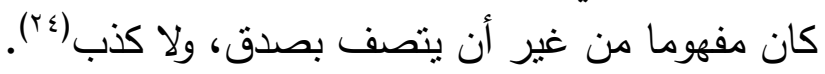

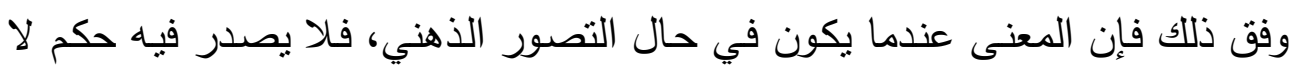

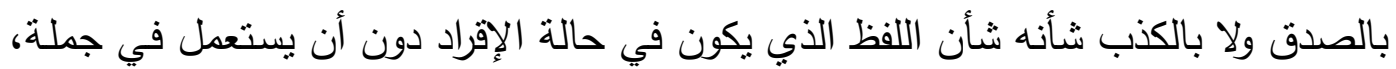

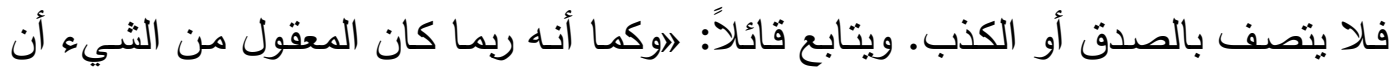

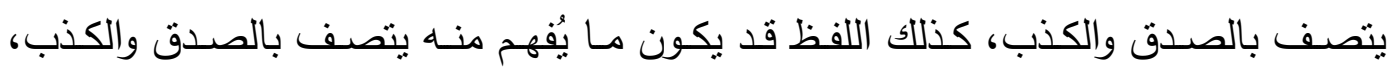




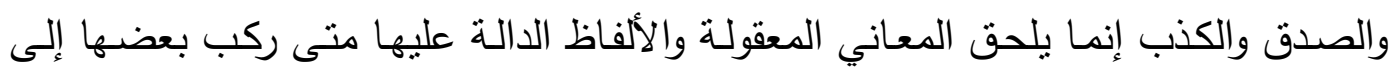
بعض، أو فصل بعضها من بعضه" (ro).

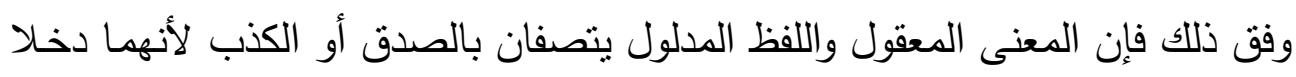

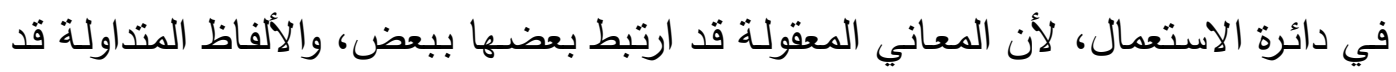

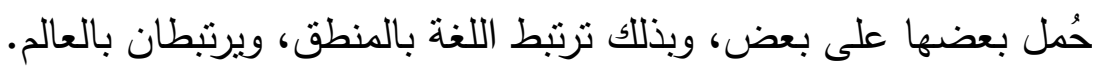

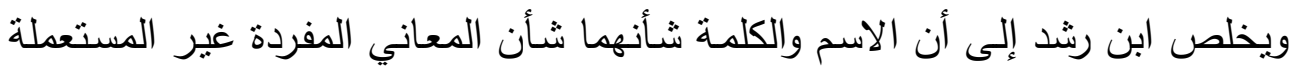

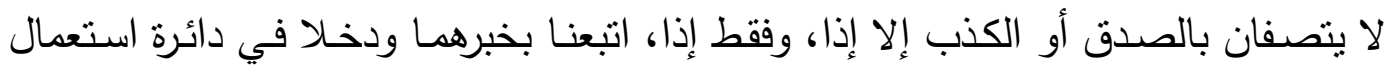

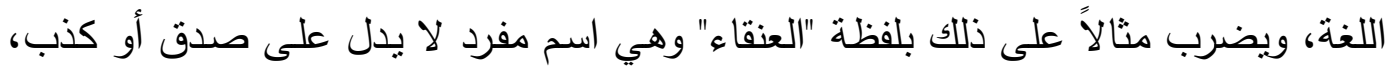

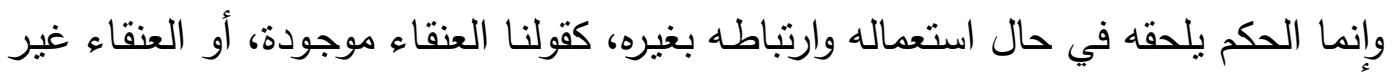

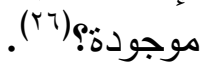

وفي موضـع آخر يذهب ابن رشد إلى توظيف اللفظ خدمة للمعنى، حيث يرى أن

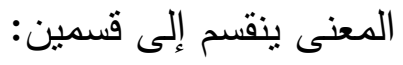

1 - معنى كلي، وهو ما يُحمل على أكثر من موضوع، ومثاله حمل الحيوان على الإنسان والفرس ... إلخ.

Y- معنى جزئي، وهو ما يدل على الفرد المشار إليه بعينه، منل زيد وفاطمة ... إلخ (YY).

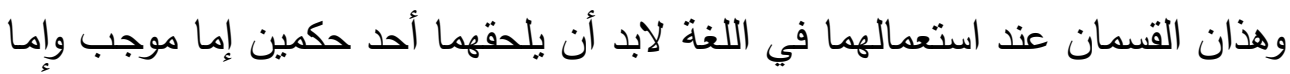
سالب، وإما عام وإما خاص، وذللك تبعًا لاستخدام السور في القضية، إما بالكل أو ألفابل بالجزء.

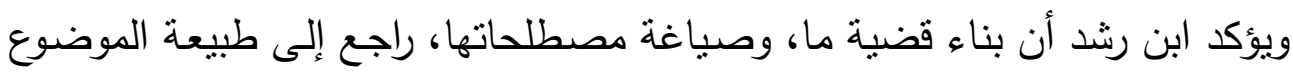

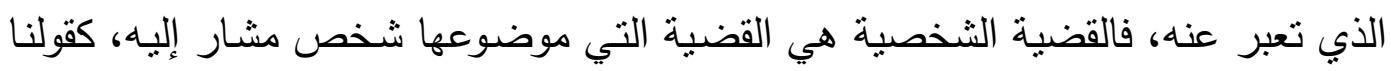

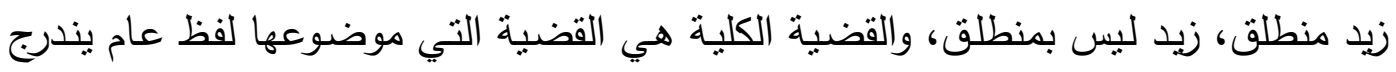

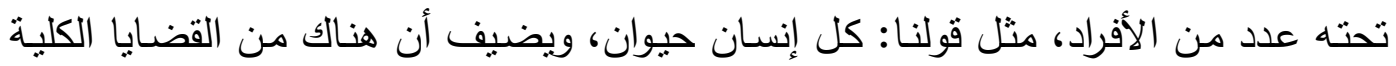
التي لا تُسبق بسور، وهي التي أسماها القضايا المهملة مثل قولنا: الإنسان أنسان أبيض، الإنسان النسان

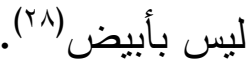

نقطة أخرى يعرضها ابن رشد في هذا الموضوع تتعلق بمفهوم النقابل وأقسامه بين القضايا، فنجده يصوغه في الحالات الآتية:

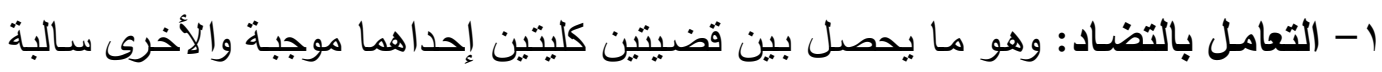

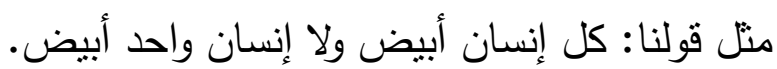


r- التقابل بالتناقض: وهو ما يحصل بين قضيتين في حالتين مختلفتين:

أ- يين قضية كلية موجبة وجزئية سالبة، منل قولنا: كل إنسان أبيض، وليس فين كل فين إنسان

أبيضن

ب- بين قضية كلية سالبة وجزئية موجبة، مثل قولنا: إنسان ما أبيض، ولا إنسان واحد

أبيض.

r- التقابل بما تحت التضاد: وهو ما يحصل بين قضيتين جزئيتين إحداهما سالبة والأخرى

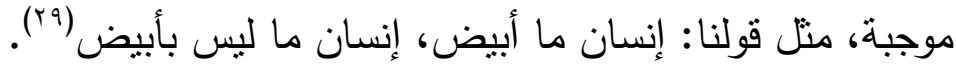

وفق ما تقدم فإن مفهومي الصدق والكذب في القضايا المتقابلة سالفة الذكر يقومان على نقطنين أساسيتين: 1- الكم، وهو مكون القضية، أبي موضوع القضية من حيث العموم والخصوص. r- الكيف، وهو حالة القضية من حيث السلب والإيجاب.

ومن المعلوم أيضًا أن القضيتين المتضادتين لا تصدقان معًا وقد تكذبان معًا، وأما

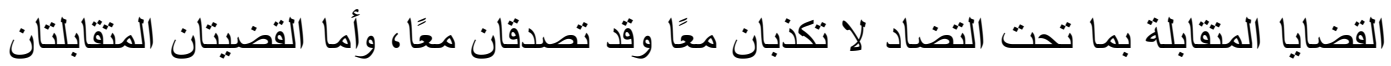
بالتتاقض فلا تصدقان معًا ولا تكذبان معًا.

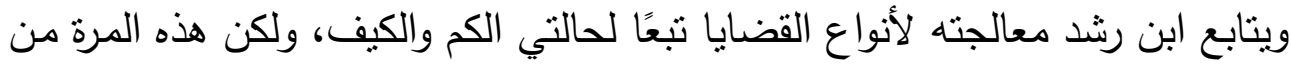
زاوية قسمة الكلام، فنجده يضيف نوعين آخرين تبعًا لكون المحمول كلمة (فعل) أو اسمًا

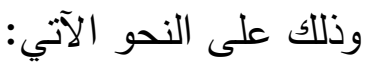

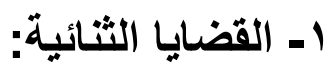

وهي القضايا التي محمولها كلمة (فعل)، وسميت بذللك لأنها مكونة من عنصرين:

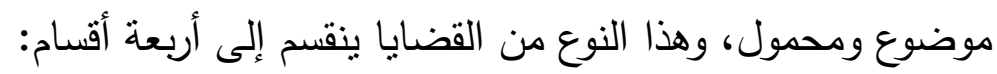
أ- الاسم الدحصل والكلمة الدحصلة، وذللك مثل قولنا: الإنسان يوجد. ب- الاسم غير المحصل والكلمة غير المحصلة، وذلك متل قولنا: لا إنسان لا يوجد. ج- الاسم المحصل والكلمة غير المحصلة، وذلك منل قولنا: الإنسان لا يوجد. د- الاسم غير المحصل والكلمة المحصلة، وذلك مثل قولنا: لا إنسان يوجد. 
وهي القضايا التي تتكون من موضوع ومحمول كلاهما اسم بينهما رابطة (كلمة)،

$$
\text { وذللك مثل: الإنسان يوجد عادلاًً) (r). }
$$

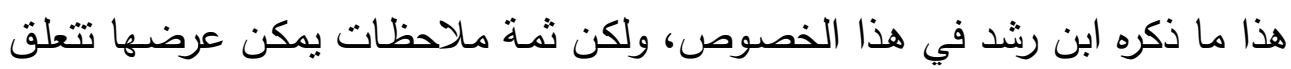

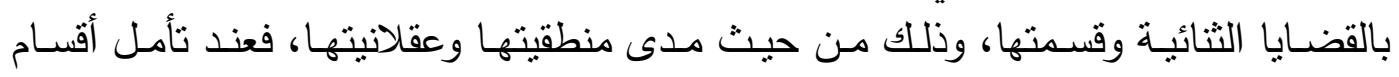

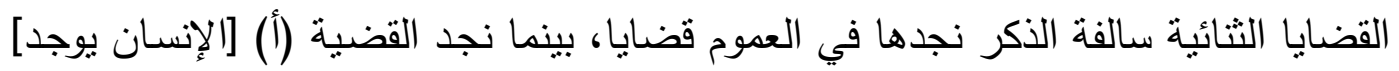

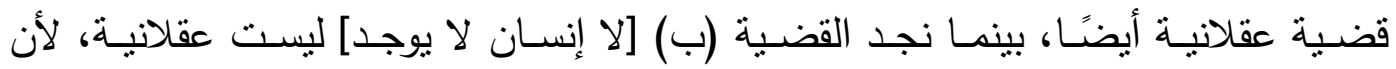

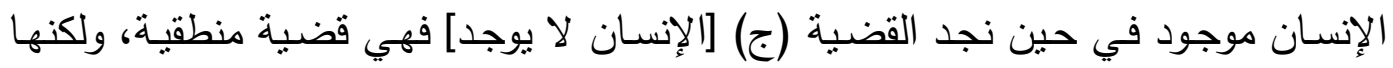

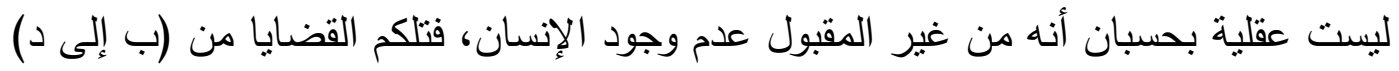
قضايا منطقية وليست عقلية.

ويضيف ابن رشد نقطة أخرى تختص ببنـاء القضية منطقيًا ومدى صلته ولته ببنائها

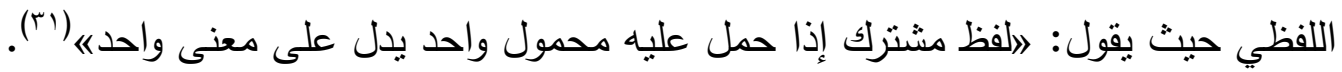

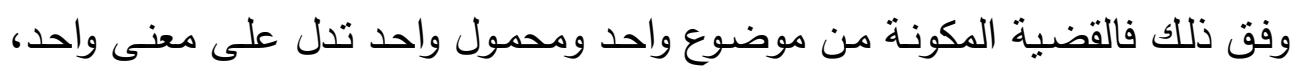

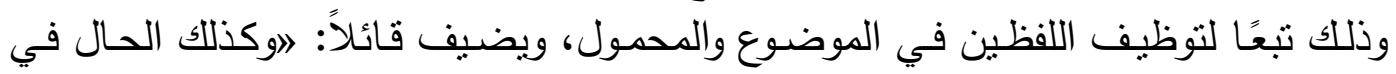

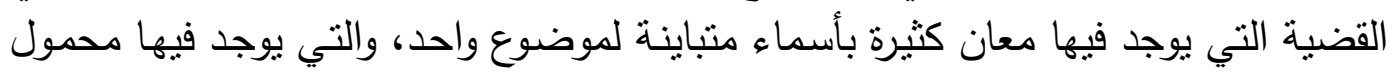

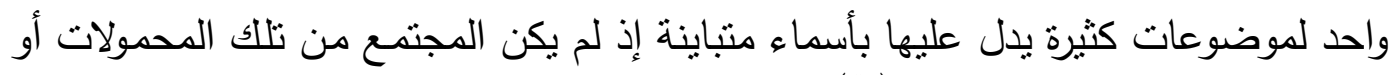

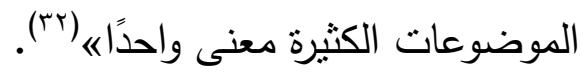

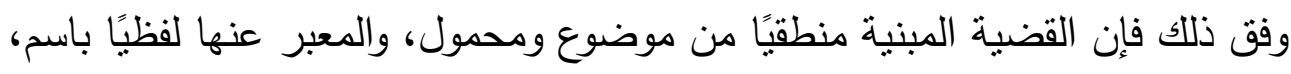

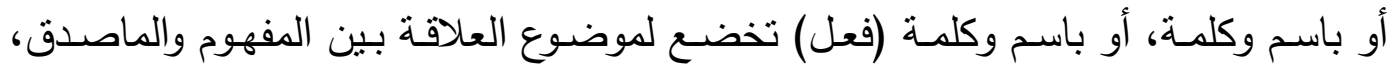

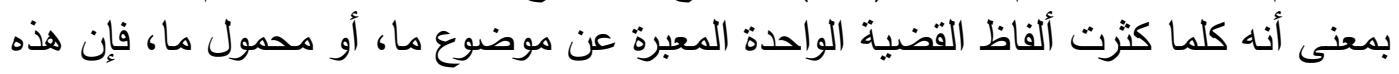

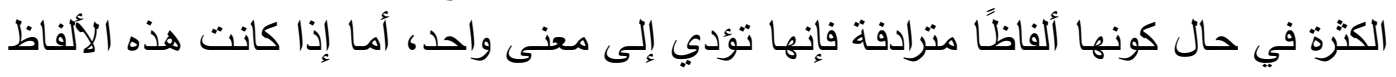

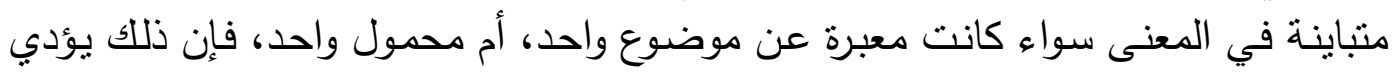

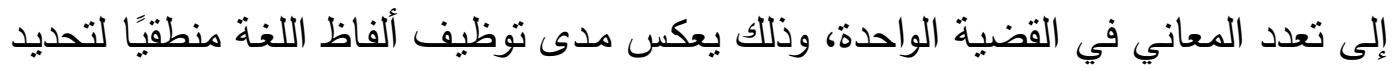
المعنى، ومدى تعبيرها عن الفكر .

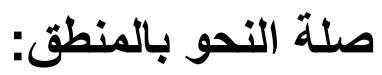

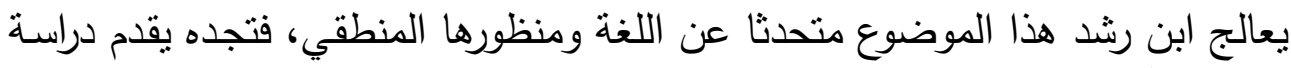

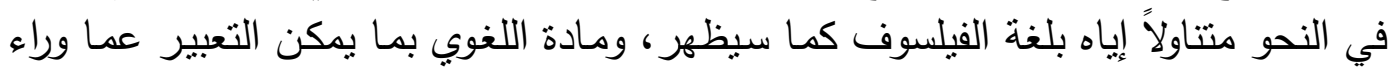




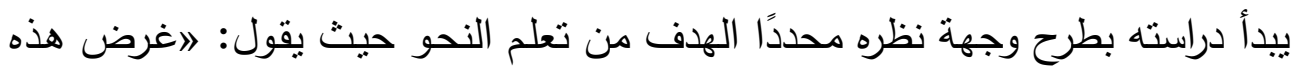

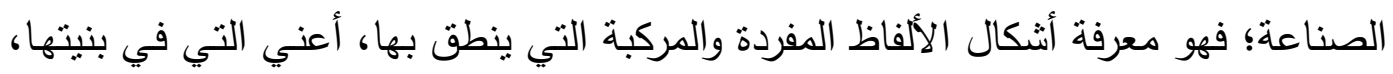

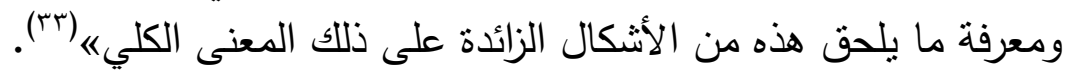

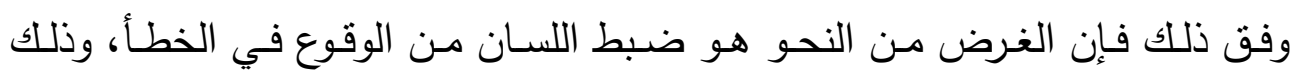

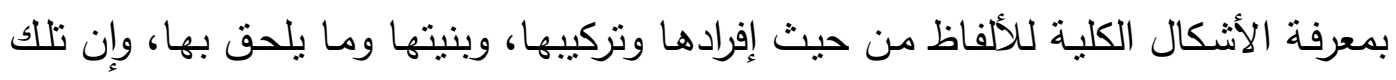

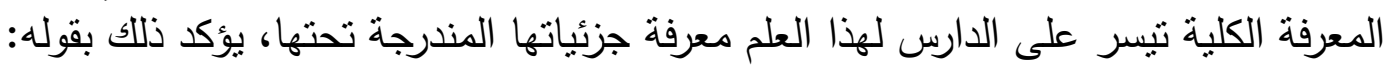

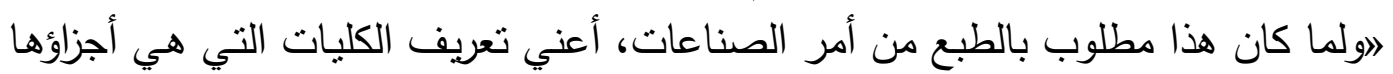

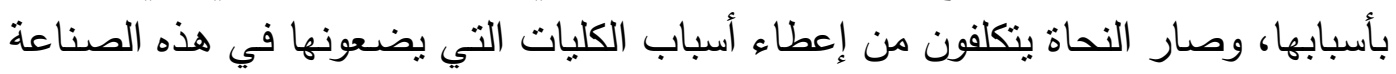

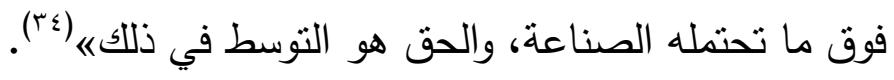

بناءً على ذلك فإن ابن رشد كان على علم بالفرّق بين المعرفة الكلية في النحو ومادته

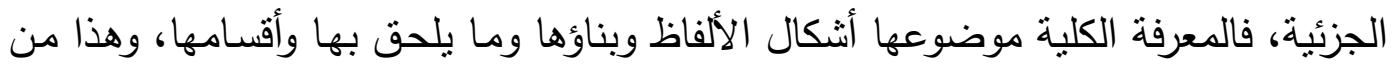

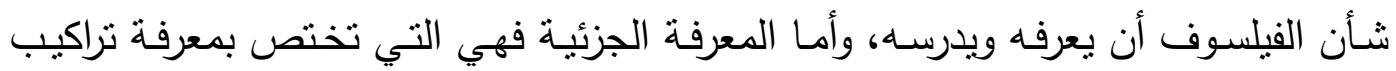

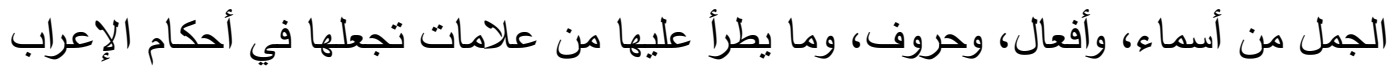

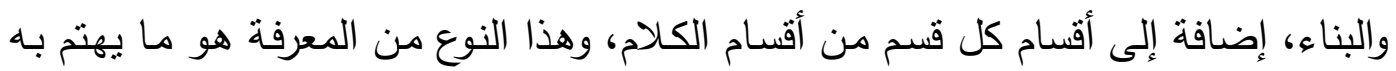

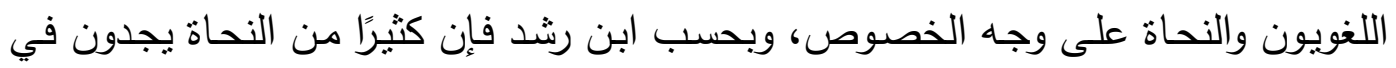
دراسة الجانب الفكري في النحو، أو لنقل المعرفة الكلية في هذا الدجال معرفة زائدة أو نرفًا فكريًا.

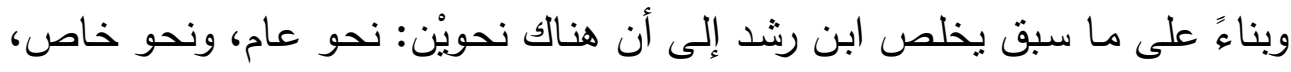

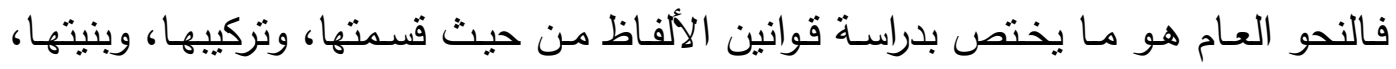

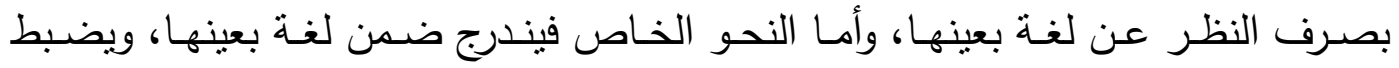

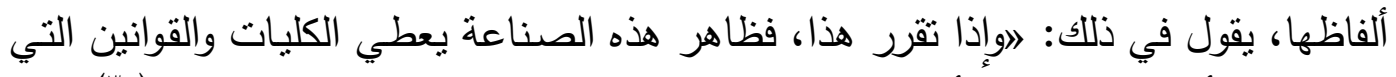
جرت عادة أهل ذلك اللسان أن ينطقوا بها، إما لسان العرب وإما غيره من الألسنةها، (ب0).

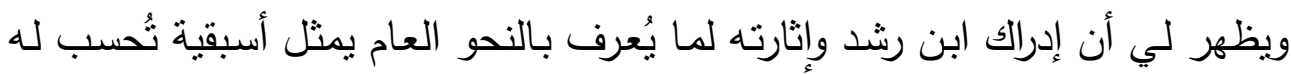

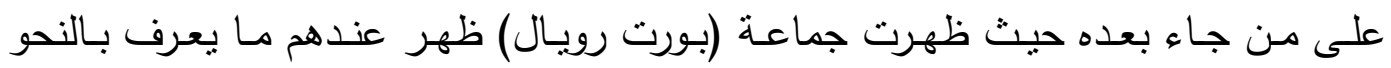

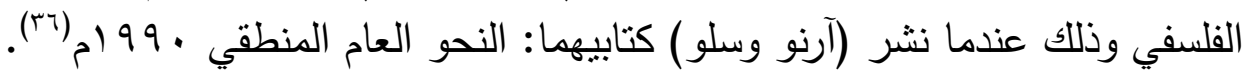

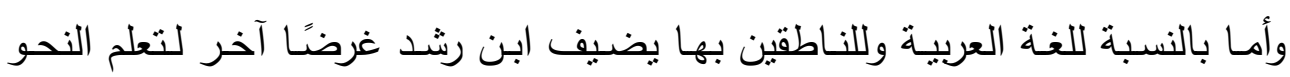
يتركز في خدمة الدين الإسلامي، وتعلم العلوم، يقول في ذلكئ لاؤأما منفعتها فبينة بنفسها، 


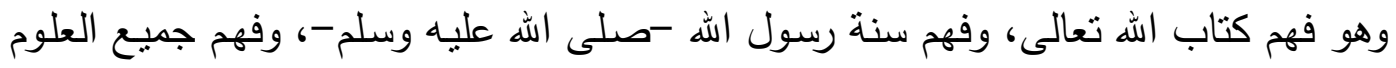

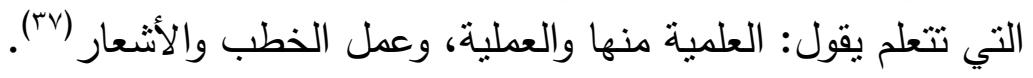

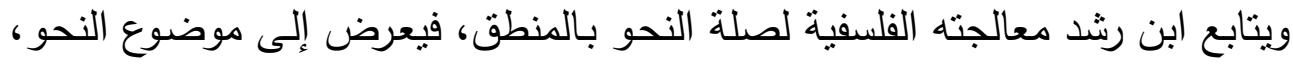

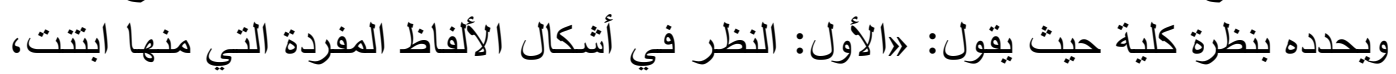

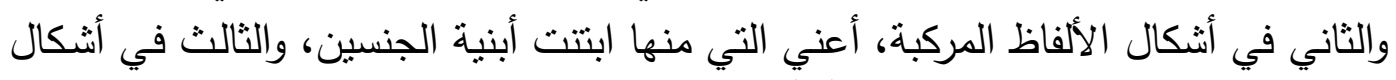

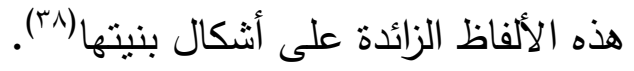

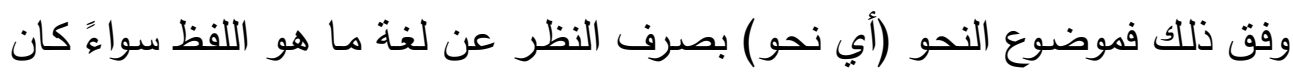

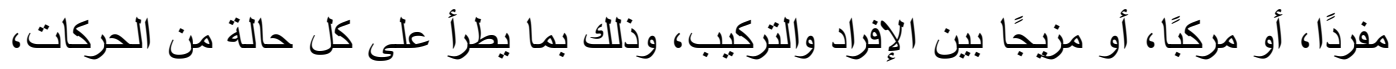

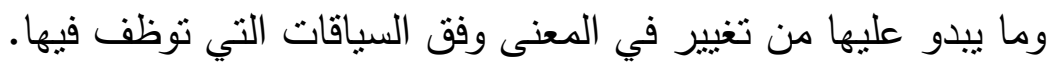

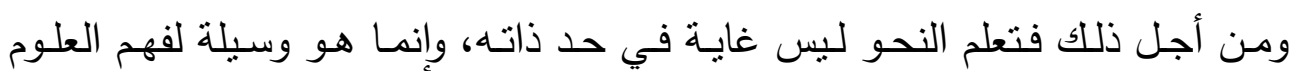

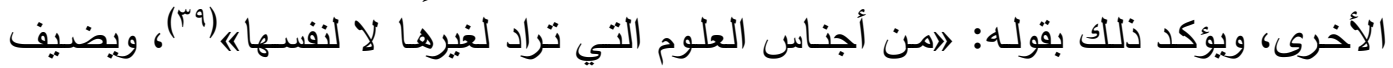

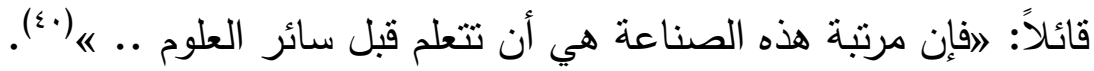

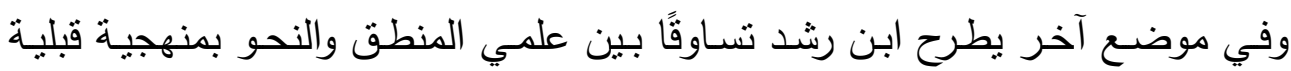

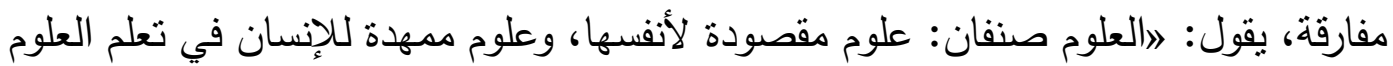

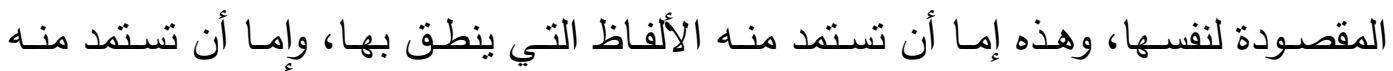

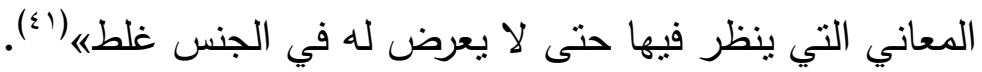

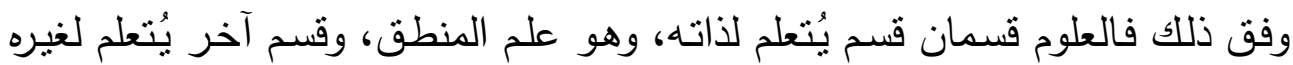

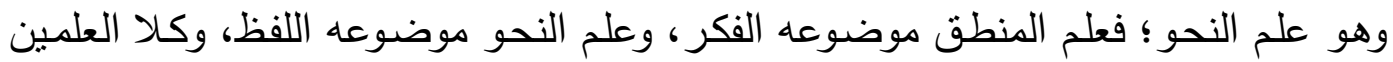

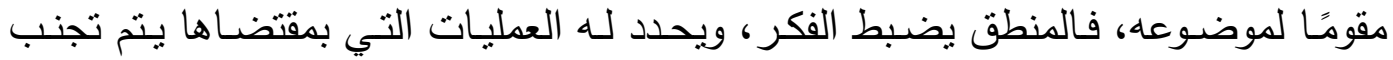

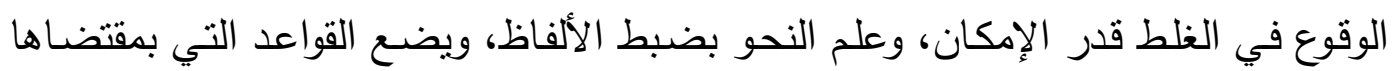

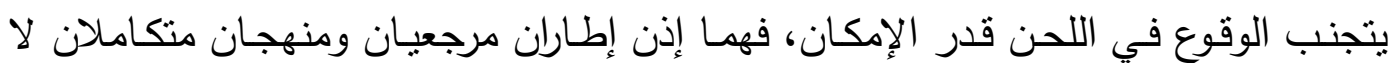

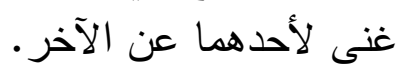

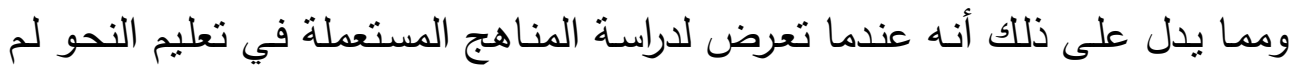

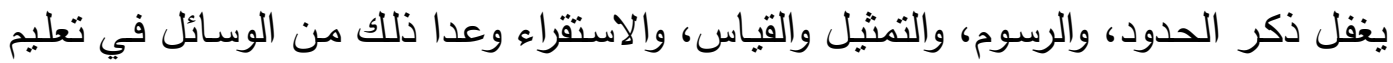

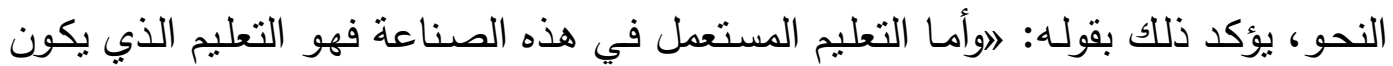

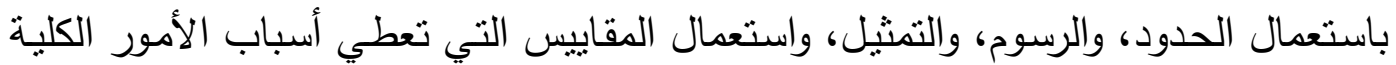

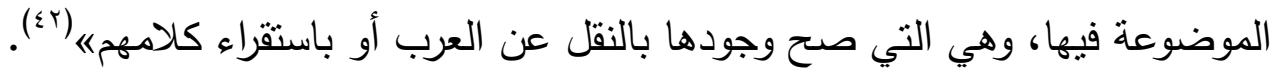




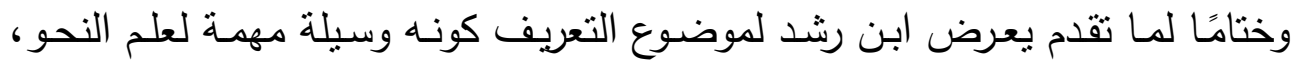

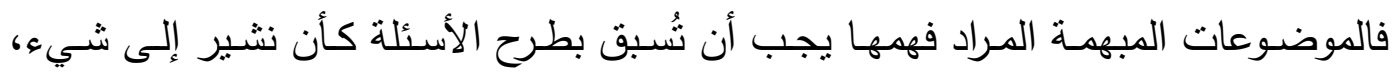

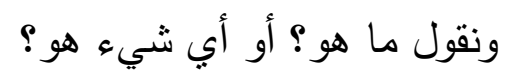

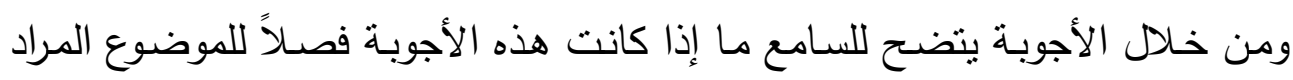

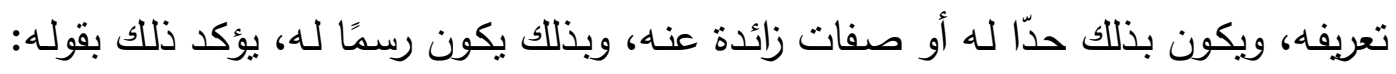

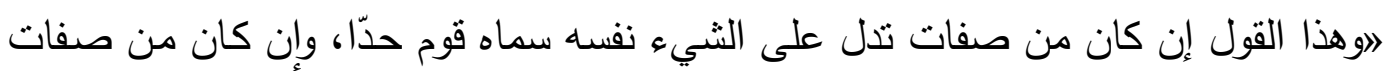

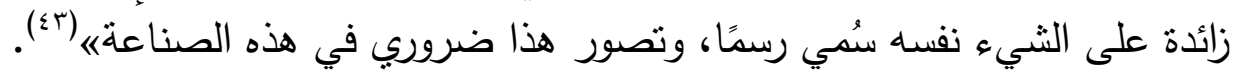

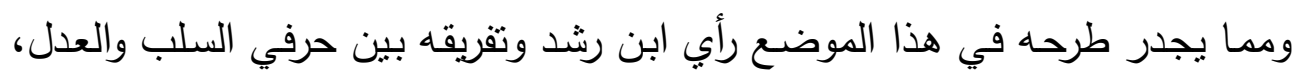

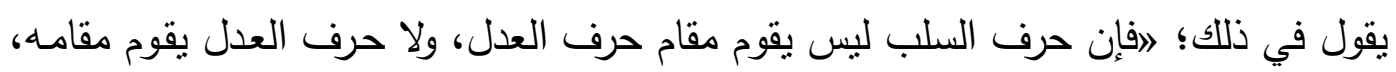

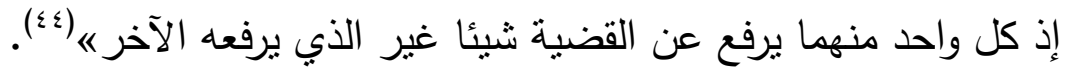

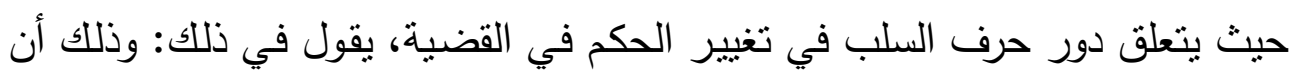

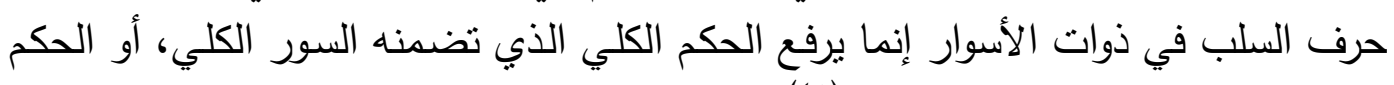

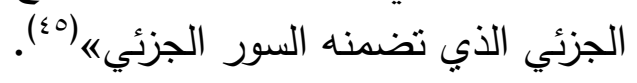

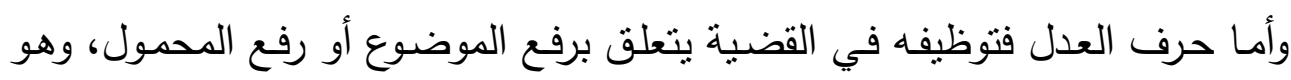

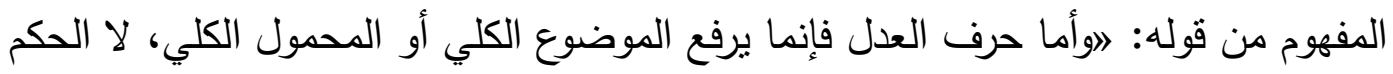

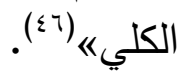




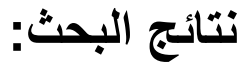

ومما تقدم طرحه نقف على جملة من النتائج يمكن صياغتها على النحو التالي:

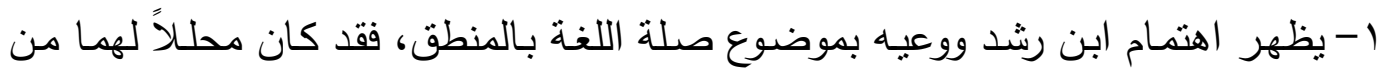

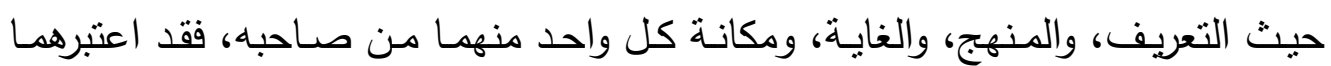

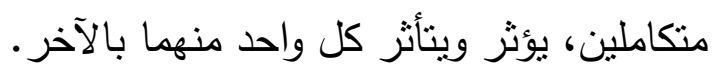

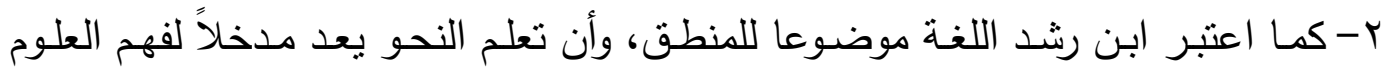

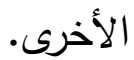

r- كان ابن رشد على وعي بالتسـاوق بين اللفظ والمعنى وعلاقتهما ببعض، وبحث في

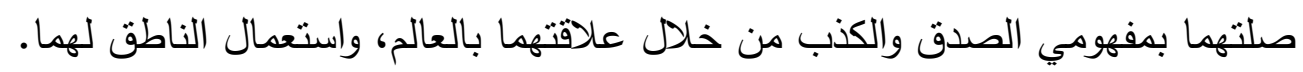

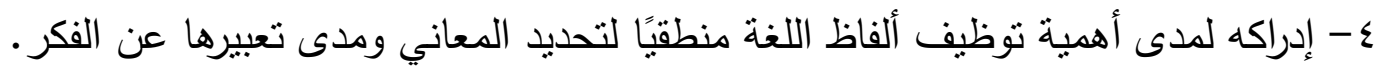
ه- عد ابن رشد تعلم النحو ضرورة لخدمة النص الديني، وفهم العلوم النظريـة والعملية، بحيث يعد كتابه "الضروري في صناعة النحو" إضافة رفيعة في الفكر اللساني العربي.

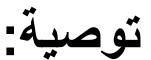

ختامًا أوصي بضرورة دراسة وبحث الفكر اللساني لدى فلاسفة المسلمين؛ وعده جزءًا

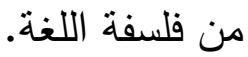




\section{الهوامش}

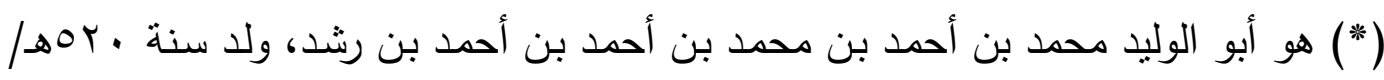

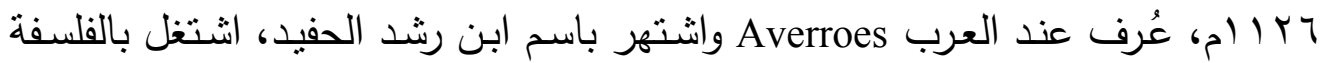
والطب والفلك والفيزياء. نشأ في أسرة من أكثر الأسر وجاهة في الأندلس ودرس الفقه على المذهب المالكي،

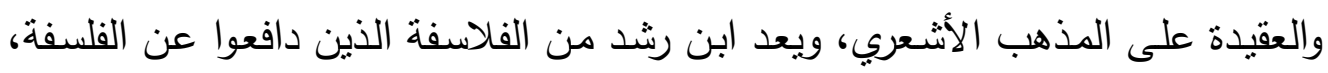

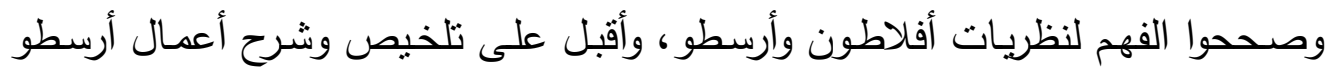

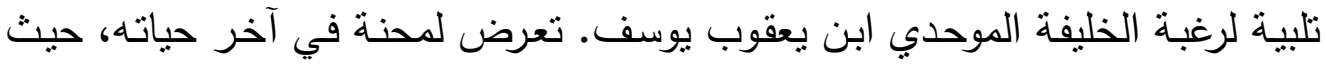

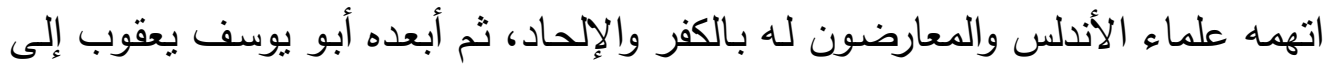

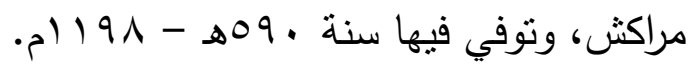

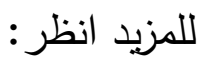

- ابن أبي أصيبعة: عيون الأنباء في طبقات الأطباء، تحقيق: عامر النجار ، د. طـ (الهيئة المصرية العامة للكتابة القاهرة، د. تأن).

- محد عابد الجابري: ابن رشد سيرة وفكر، ط ا (مركز دراسـات الوحدة العربية،

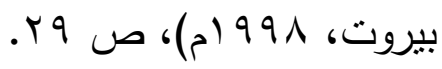
- عاطف العراقي: الفيلسوف ابن رشد ومستقبل التقافة العربية، طا (دار الرشاد، القاهرة

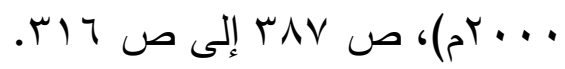
- عبد الرحمن التليلي: ابن رشد في الدصادر العربية، طا (المجلس الأعلى للتقافة،

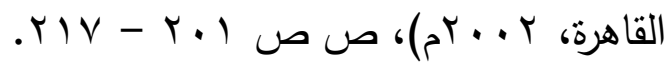
- عباس محمود العقاد: نوابغ الفكر العربي ابن رشد، د، ط (دار المعارف، الإسكندرية،

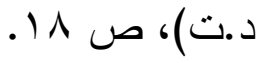

- Dominique Urvey: Ibn Rush translated by Olivia Stewart (American University, Cairo Press, 1993), PP. 29 - 38.

(1) ابن رشد: نلخيص كتاب العبارة، تحقيق وتعليق: محمد سليم سالم، د. ط (مطبعة دار

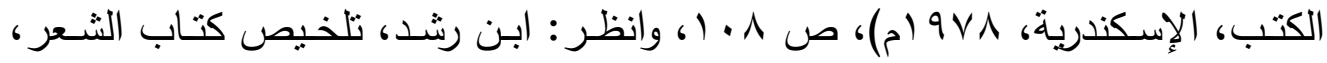

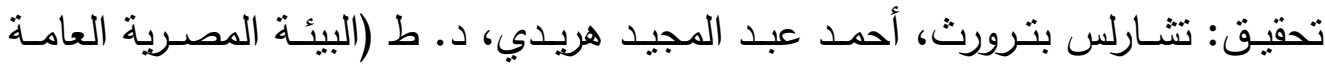

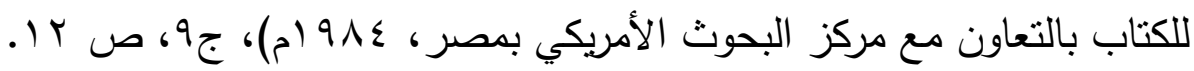




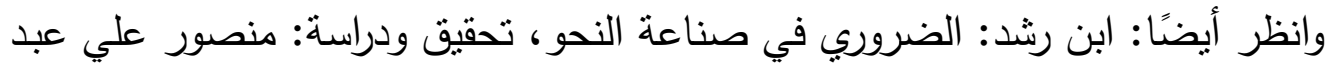

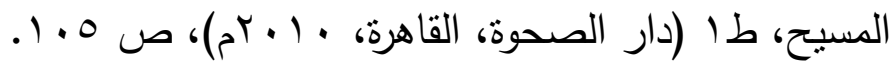

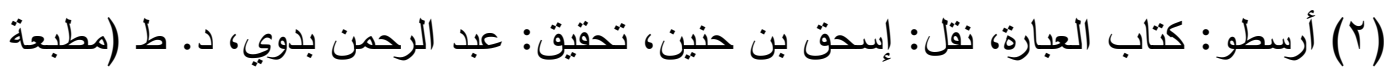

$$
\begin{aligned}
& \text { دار الكتب المصرية، القاهرة، } 9 \text { (9 (م). } \\
& \text { وانظر أيضًا: }
\end{aligned}
$$

Deborah, K. W., Modrak: Aristotale's Theory of Language and Meaning (Cambridge University Press, United States of American, 2001), p. 43.

(ץ) الفارابي: كتاب العبارة، تحقيق: محمد سليم سالم، د. ط (مطبعة دار الكتب، مصر ،

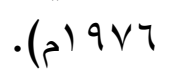

(ع) ابن رشد: تلخيص العبارة، تحقيق: جيرار جيهامي، طا (دار الفكر اللبناني، بيروت،

(7) انظر : ابن رشد: الضـروري في صناعة النحو، تحقيق ودراسـة: منصسور علي عبد

$$
\begin{aligned}
& \text { السميع، طا (دار الصحوة، القاهرة، · (· بام). } \\
& \text { ابن رشد: تلخيص كتاب العبارة، ص VV) }
\end{aligned}
$$

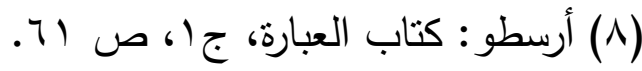

$$
\begin{aligned}
& \text { وانظر أيضًا: }
\end{aligned}
$$

Deborah, K. W., Modrak: Aristotale's Theory of Language and Meaning, p. 44.

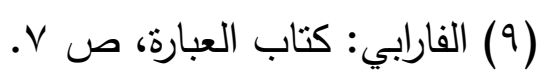

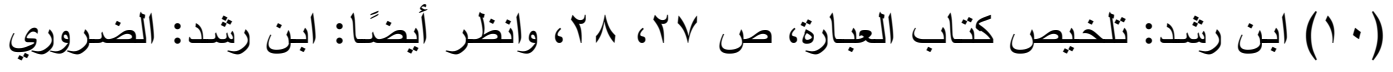

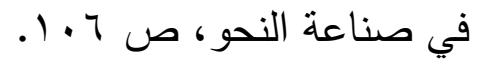

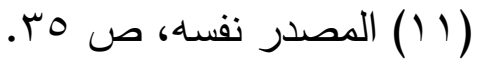

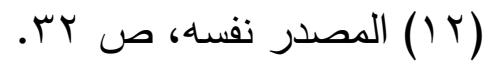

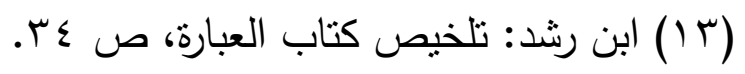

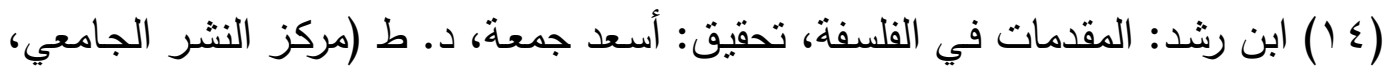

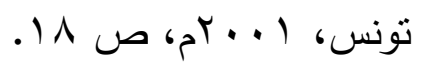


(10) ابن رشد، الضروري في صناعة النحو، مصدر سابق، ص 1 ـ 1. 17.

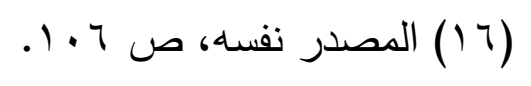

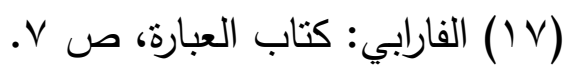

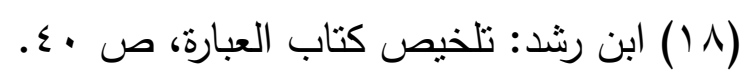

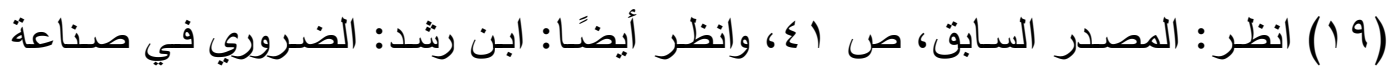

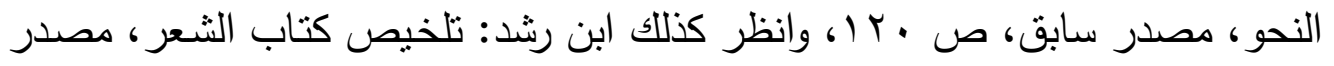

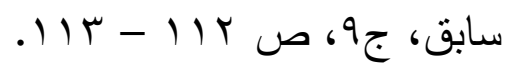

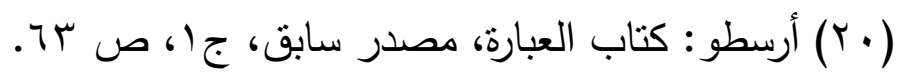

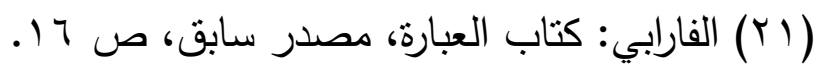

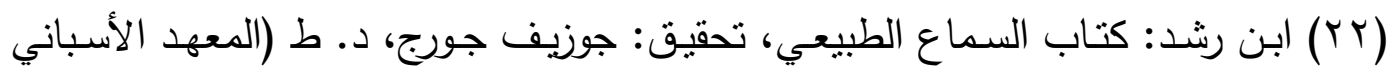

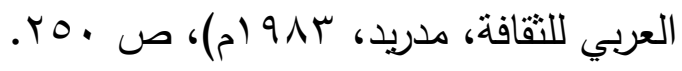

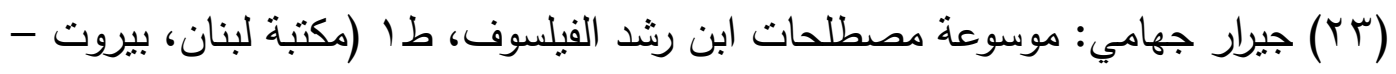

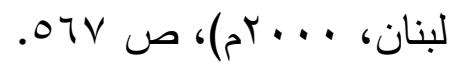

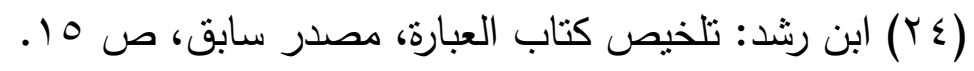

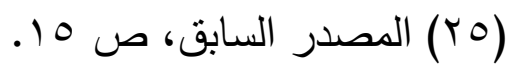

(Y)

.00 (YV)

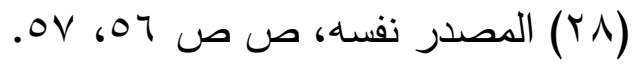

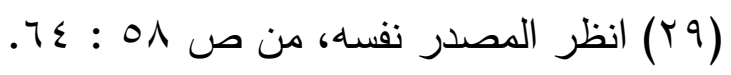

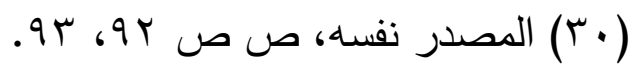

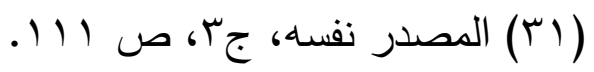

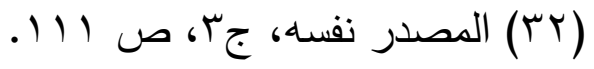

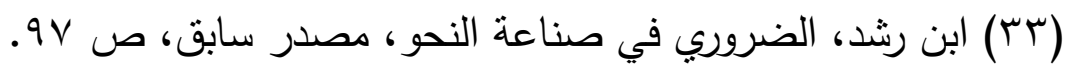

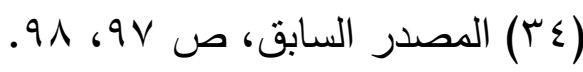




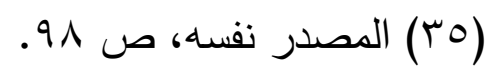

(דr) انظر: عبد الرحمن بدوي: المنطق الصوري والرياضي، طب (مكتبة النهضة المصرية،

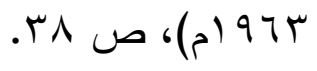

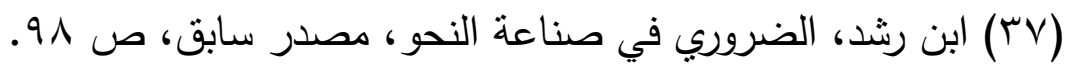

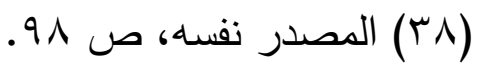

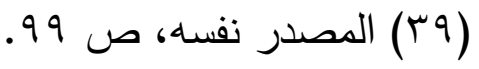

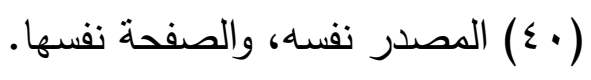

( (

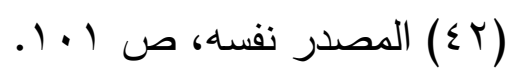

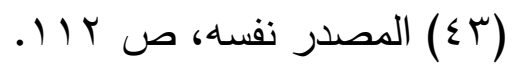

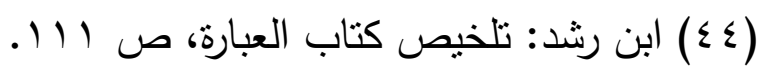

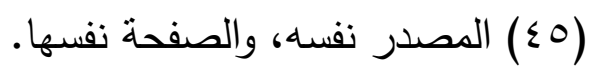

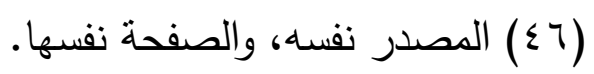




\section{ثبت المصادر والمراجع}

1- أرسطو : كتاب العبارة، نقل: إسحق بن حنين، تحقيق: عبد الرحمن بدوي، د. ط البـ (مطبعة

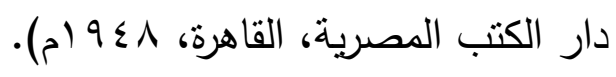

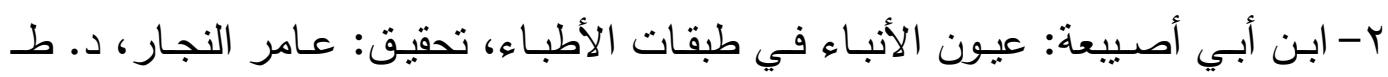

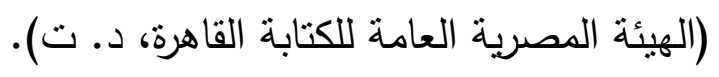

r- جيرار جهامي: موسوعة مصطلحات ابن رشد الفيلسوف، طا (مكتبة لبنان، بيروت -

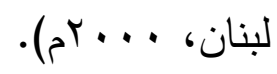

ع - ابن رشد: تلخيص كتاب السفسطة، تحقيق وتعليق: محمد سليم سالم، د. ط (مطبعة دار

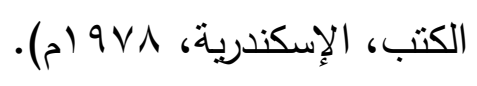

0- -----: تلخيص كتاب الثعر ، تحقيق: تشارلس بترورث، أحمد عبد المجيد هريدي، د. د.

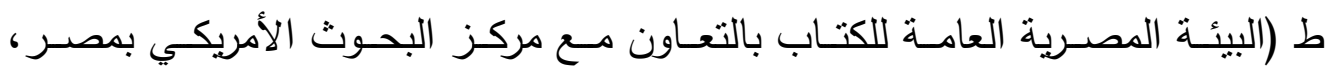

צ-------: تلخيص العبارة، تحقيق: جيرار جيهامي، طا (دار الفكر اللبناني، بيروت،

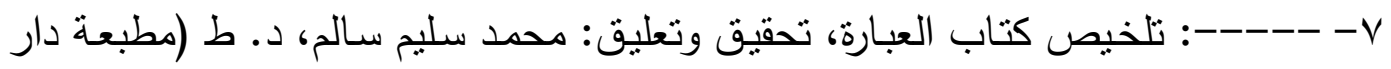

$$
\text { الكتب، الإسكندرية، } 9 \vee 1 \text { (م). }
$$

1------- الضروري في صناعة النحو، تحقيق ودراسة: منصور علي عبد المسيح، طا

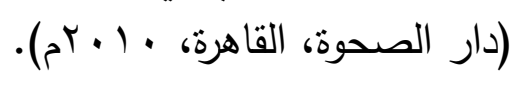

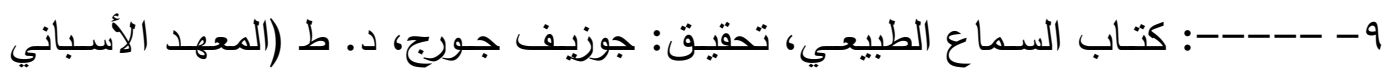

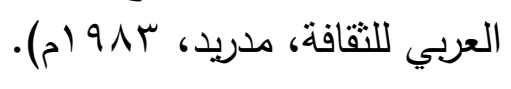

•

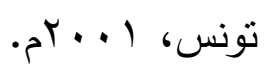

1)

$$
\text { . }
$$

r إ- عباس محمود العقاد: نوابخ الفكر العربي ابن رشد، د، ط (دار المعارف، الإسكندية، د.ت). 


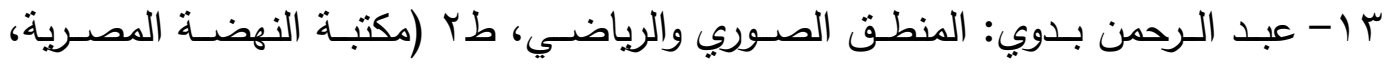
(م)

ع ا- عبد الرحمن التليلي: ابن رشد في المصـادر العربية، طا (المجلس الأعلى للتقافة،

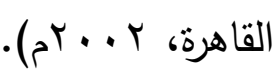

10 - محمد عابـ الجـابري: ابـن رشــ سـيرة وفكر ، ط ا (مركز دراسـات الوحدة العربيـة،

$$
\text { بيروت، } 991 \text { (م). }
$$

16- Deborah, K. W., Modrak: Aristotale's Theory of Language and Meaning (Cambridge University Press, United States of American, 2001).

17- Dominique Urvey: Ibn Rushd, translated by Olivia Stewart, (American University, Cairo Press, 1993). 
rAT 